\title{
Malignant Oral Neoplasm
}

National Cancer Institute

\section{Source}

National Cancer Institute. Malignant Oral Neoplasm. NCI Thesaurus. Code C9316.

A primary or metastatic malignant neoplasm that affects the lip and/or oral cavity. The majority of cases are carcinomas. 